\title{
Memberikan Promosi Kesehatan di Rumah Sakit dan Edukasi Guna Meningkatkan Keselamatan Pasien
}

Aruni Muharani

\author{
arunikisaran@gmail.com
}

\section{LATAR BELAKANG}

Promosi kesehatan di rumah sakit merupakan aspek penting dalam menilai komitmen akreditasi rumah sakit (KARS).

Promosi kesehatan mempunyai pengertian dan arti yang sangat relevan. Pengertian promosi kesehatan menurut Permenkes No. 44 tahun 2018 tentang penyelenggaraan PKRS adalah proses untuk memberdayakan masyarakat melalui suatu kegiatan menginformasikan, mempengaruhi dan membantu masyarakat agar berperan aktif untuk mendukung perubahan perilaku dan lingkungan serta menjaga dan meningkatkan kesehatan menuju derajat kesehatan yang optimal (Menkes, 2018).

Rumah sakit adalah institusi pelayanan kesehatan yang menyelenggarakan pelayanan kesehatan secara paripurna yaitu pelayanan kesehatan yang meliputi promotif, preventif, kuratif, dan rehabilitatif. Hal ini bertujuan untuk meningkatkan mutu dan mempertahankan standar pelayanan rumah sakit serta memberikan perlindungan terhadap keselamatan pasien, masyarakat, lingkungan rumah sakit dan sumber daya manusia di rumah sakit. Rumah sakit dalam meningkatkan mutu pelayanan memerlukan standar untuk memaksimalkan proses pelayanan melalui Promosi Kesehatan Rumah Sakit (PKRS) (Menkes, 2018).

Promosi kesehatan sendiri mencakup aspek perilaku, aspek perilaku yaitu upaya untuk memotivasi, mendorong dan membangkitkan kesadaran akan potensi yang dimiliki masyarakat agar mereka mampu memelihara dan meningkatkan kesehatannya.

Undang-undang Nomor 36 Tahun 2009 tentang Kesehatan menyatakan bahwa setiap orang berhak untuk mendapatkan informasi dan edukasi tentang kesehatan yang seimbang dan bertanggung jawab dan setiap orang berhak memperoleh informasi tentang data kesehatan dirinya termasuk tindakan dan pengobatan yang telah maupun yang akan diterimanya dari tenaga kesehatan. 


\section{METODE}

Metode yang dilakukan dalam penulisan ini adalah metode kepustakaan yaitu dengan melakukan peninjauan dan mengumpulkan data-data yang diperoleh dari buku dan jurnal-jurnal terkini kemudian menganalisis data-data tersebut dan mereview. Pengolahan data dilakukan mulai dari menganalisis isi buku dan jurnal hingga kesimpulan dari penulis. jurnal atau artikel yang didapatkan dengan menggunakan Google Scholar, dan Jurnal Keperawatan Indonesia.

\section{HASIL}

Berdasarkan hasil dari metode pencarian literature review didapatkan bahwa keselamatan pasien sangat berpengarus bagi suatu instalasi rumah sakit karena hal itu merupakan komponen penting fungsi, tujuan dan peran dari rumah sakit. Kebijakan keselamatan pasien di rumah sakit menurut hasil yang didapatkan dari beberapa jurnal banyak dipengaruhi oleh berbagai faktor-faktor yang berhubungan dengan implementasi keselamatan pasien di rumah sakit.

Penerapan keselamatan pasien di rumah sakit berhasil tergantung dengan kemampuan tenaga kesehatan untuk menerapkan dan mempunyai ilmu pengetahuan mengenai kesalamatan pasien. Berdasarkan jurnal yang dianalisis pemimpin suatu rumah sakit mempunyai pengaruh dalam meningkatkan keselamatan dan menyelesaikan permasalahan keselamatan pasien yang ada dalam rumah sakit. Pemimpin menginterpretasikan, mengansumsikan dan memberikan penilaian terhadap persoalan dan akan memberikan solusi baik menyangkut pengetahuan, sikap maupun tindakan yang harus dijalankan agar keselamatan pasien tetap terjaga.

Berdasarkan salah satu jurnal didapatkan hasil observasi pelaksanaan promosi kesehatan padaRumah Sakit Universitas Airlangga, menunjukkan bahwa Promosi Kesehatan Rumah Sakit (PKRS) yang dilakukan telah merujuk pada Standar Promosi Kesehatan Rumah Sakit oleh PKRS Tahun 2010 dan Permenkes RI No. 4 Tahun 2012 mengenai Petunjuk Teknis PKRS. Kegiatan PKRS yang ada di Rumah Sakit Universitas Airlangga tidak hanya dilaksanakan dalam gedung rumah sakit, namun juga di luar gedung. Tim PKRS Rumah Sakit Universitas Airlangga telah melakukan kegiatan promosi kesehatan, sehingga dapat dipastikan tujuan dari PKRS yakni 
terciptanya masyarakat rumah sakit yang dapat menerapkan PHBS melalui perubahan sikap, pengetahuan, serta perilaku pasien/klien rumah sakit dan dapat memelihara lingkungan rumah sakit beserta pemanfaatan semua layanan yang tersedia dalam rumah sakit akan tercapai di RS Univeritas Airlangga.

\section{PEMBAHASAN}

Rumah sakit merupakan salah satu pelayanan jasa yang di dalamnya terdapat banyak aktivitas yang tidak terlepas dari perkembangan ilmu pengetahuan dan teknologi. Setiap proses pelayanan kesehatan di rumah sakit ada beberapa faktor penting pendukung pelayanan kesehatan yang saling berkaitan satu dengan yang lain. Diantaranya meliputi pasien, tenaga kerja, mesin, lingkungan kerja, cara melakukan pekerjaan serta proses pelayanan kesehatan. Dalam faktor-faktor tersebut ada resiko yang harus di hindari atau perlu ditangani. Untuk penanganan resikonya dilakukan oleh para tenaga kesehatan yang memberikan pelayanan.Penanganan resiko bahaya yang terdapat dirumah sakit dengan cara melakukan eliminasi, substitusi, rekayasa dan administratif.

Promosi Kesehatan pada Rumah Sakit (PKRS) merupakan usaha untuk menambah wawasan dari pasien, keluarga pasien, dan pengunjung rumah sakit tentang berbagai macam penyakit dan cara pencegahan yang benar, selain itu promosi kesehatan di Rumah Sakit merupakan upaya Rumah Sakit untuk meningkatkan kemampuan pasien, keluarga serta pengunjung rumah sakit agar dapat berperan secara positif dalam usaha penyembuhan dan pencegahan terhadap penyakit sehingga dapat mempercepat proses kesembuhan dan rehabilitasinya, meningkatkan kesehatan, mencegah masalah kesehatan, dan mengembangkan upaya kesehatan melalui pembelajaran sesuai sosial budaya masing-masing secara mandiri

Pembangunan kesehatan memiliki sebuah tujuan, yaitu membuat setiap orang lebih sadar, lebih mau, dan lebih mampu untuk menjalani hidup yang sehat. Hal ini bertujuan agar derajat kesehatan yang optimal dapat terwujud di negara ini, sehingga rumah sakit sebagai salah satu institusi pelayanan kesehatan memiliki peran yang sangat tepat untuk dapat mencapai tujuan tersebut (Depkes RI, 2000).

Perkembangan paradigma promosi kesehatan pada rumah sakit di Indonesia berawal pada tahun 1994, dimana masih bernama Promosi Kesehatan Masyarakat Rumah Sakit 
(PKMRS). Istilah promosi kesehatan masyarakat rumah sakit (PKMRS) diubah dengan nama Promosi Kesehatan Rumah Sakit pada tahun 2003. Sejumlah program yang berada pada naungan program PKRS telah banyak dilaksanakan, misalnya advokasi, menyusun sebuah program untuk PKRS, dan melaksanakan sosialisasi tentang program PKRS kepada direktur dari Rumah Sakit Pemerintah. Pelatihan PKRS, pengembangan dan distribusi media serta pengembangan model dan PKRS (Depkes RI, 2010).

Sebagai tempat sarana kesehatan, Rumah sakit haruslah sudah terintegrasi dengan baik dalam sistem kesehatan. Rumah sakit berfungsi sebagai sumber daya bagi peningkatan kesehatan masyarakat di wilayah yang bersangkutan. Rumah sakit di Indonesia hanya menekankan pada pelayanan kuratif dan rehabilitatif saja, keadaan inilah yang menyebabkan rumah sakit menjadi sarana kesehatan elit dan terlepas dari sistem kesehatan sehingga adanya reformasi rumah sakit di Indonesia pun sangat diperlukan (Depkes RI, 2012).

Rumah sakit harus menyelenggarakan fungsi antara lain (Permenkes, 2012):

1. Penyelenggaraan pelayanan pengobatan dan pemulihan kesehatan sesuai dengan standar pelayanan rumah sakit

2. Pemeliharaan dan peningkatan kesehatan perorangan melalui pelayanan kesehatan paripurna tingkat dua dan ketiga sesuai kebutuhan medis

3. Penyelanggaraan pendidikan dan pelatihan sumber daya manusia dalam rangka peningkatan kemampuan dalam pemberian pelayanan kesehatan

4. Penyelenggaraan penelitian dan pengembangan serta penapisan teknologi di bidang kesehatan dalam rangka meningkatkan pelayanan kesehatan dengan memperhatikan etika ilmu pengetahuan bidang kesehatan

Pelaksanaan promosi kesehatan rumah sakit (PKRS) sangat bermanfaat untuk menambah wawasan untuk pasien dan keluarganya, serta pengunjung di rumah sakit tentang beragam jenis penyakit serta langkah apa saja yang diperlukan untuk pencegahannya, selain itu promosi kesehatan di rumah sakit merupakan upaya rumah sakit untuk meningkatkan kemampuan pasien, keluarga dan pengunjung rumah sakit agar dapat berperan secara positif dalam usaha penyembuhan dan pencegahan terhadap penyakit sehingga dapat mempercepat proses penyembuhan serta rehabilitasi, meningkatkan kesehatan, mencegah terjadinya penyakit, serta 
mengembangkan berbagai upaya untuk meningkatan kesehatan masyarakat melalui pembelajaran sesuai dengan sosial dan budaya masing-masing secara mandiri (Depkes RI, 2011).

Pentingnya promosi kesehatan di rumah sakit karena efektivitas suatu pengobatan, selain dipengaruhi oleh pola pelayanan kesehatan yang ada, sikap dan keterampilan para unit PKRS, juga sangat dipengaruhi oleh lingkungan, sikap, pola hidup pasien, dan keluarga pasien serta tergantung pada tingkat kerja sama yang positif antara personel kesehatan dengan pihak pasien beserta keluarganya. Pembangunan kesehatan diarahkan untuk meningkatan tingkat kesadaran, kemauan dan kemampuan hidup sehat seseorang agar peningkatan derajat kesehatan masyarakat dapat terwujud setinggi-tingginya. Tujuan dari Promosi Kesehatan Rumah Sakit adalah agar terciptanya masyarakat rumah sakit yang mampu menerapkan Perilaku Hidup Bersih dan Sehat (PHBS) melalui perubahan pengetahuan, sikap, dan perilaku pasien Rumah Sakit serta pemeliharaan lingkungan rumah sakit dan dapat memanfaatkan semua pelayanan yang disediakan oleh Rumah Sakit dengan baik (Depkes RI, 2011).

Promosi kesehatan dapat dilakukan di semua tempat khususnya di rumah sakit. Tempat ibadah di RSUD dr. Soekardjo sangat rapi, nyaman dan sangat bersih. Jadi meskipun tidak ada pesan-pesan kesehatan secara langsung di mesjid tersebut. Namun pesan secara tersirat untuk menjaga lingkungan agar tetap bersih terlihat sangat jelas meskipun tidak tertulis secara langsung. Sedangkan untuk PKRS di kantin/toko-toko/kios-kios dari hasil observasi yang peneliti lakukan.

Secara umum promosi kesehatan memiliki peluang yang dikategorikan sebagai berikut (Permenkes, 2012): 1. Di dalam gedung rumah sakit, PKRS dilakukan seiring dengan pelayanan yang diselenggarakan rumah sakit, sehingga dapat dikatakan bahwa di dalam gedung terdapat beberapa peluang seperti seperti: a. PKRS di tempat pendaftaran atau administrasi, yaitu tempat dimana pasien atau klien harus melakukan pendaftaran terlebih dahulu sebelum mendapatkan pelayanan dari rumah sakit. b. PKRS dalam pelayanan rawat jalan bagi pasien, yaitu terdapat pada poliklinik seperti kebidanan, anak, mata, penyakit dalam, THT, dan lain-lain. c. PKRS dalam pelayanan rawat inap bagi pasien, yaitu terdapat pada ruang rawat darurat, intensif, dan inap. d. PKRS dalam pelayanan penunjang medik bagi pasien, yaitu pelayanan obat/apotek, laboratorium, dan pelayanan rehabilitasi medik, serta kamar mayat. e. PKRS dalam pelayanan bagi klien, seperti pelayanan KB, konseling gizi, pemeriksaan kesehatan dan lain-lain. f. PKRS 
di ruang pembayaran rawat inap, yaitu dalam ruangan tempat pasien rawat inap dan harus menyelesaikan pembayaran biaya dari rawat inap tersebut.

2. Di luar gedung rumah sakit, dapat dimanfaatkan secara maksimal untuk pelaksanaan PKRS, seperti:

a. PKRS di tempat parkir, yaitu pemanfaatan beberapa ruang yang terdapat pada tempat parkir mulai dari bangunan gardu sampai ke tiap sudut dari lapangaan parkir.

b. PKRS di taman sekitar rumah sakit, baik taman yang berada di depan, samping, dan belakang rumah sakit.

c. PKRS pada dinding luar rumah sakit.

d. PKRS pada tempat-tempat umum seperti tempat ibadah, kantin atau kios yang tersedia di wilayah rumah sakit. e. PKRS di pagar pembatas kawasan rumah sakit.

Monitoring dan evaluasi untuk terlaksananya pencatatan edukasi di rekam medik dilakukan setiap 6 (enam) bulan, dan hasilnya disampaikan juga pada rapat koordinasi semua PPA sebagai bahan tindak lanjut. Laporan PKRS secara menyeluruh dilakukan tiap 6 (enam) bulan. Hasil laporan tersebut selain di sampaikan di internal, juga di sampaikan ke Dinas Provinsi sebagai laporan rutin. Bahkan evaluasi program kerja selama setahun juga sudah dilakukan oleh instalai PKRS.

Berdasarkan peraturan dari perundang-undangan tentang rumah sakit yaitu Permenkes No. 4 Tahun 2012 mengenai petunjuk teknis PKRS, menyatakan bahwa setiap rumah sakit harus melaksanakan usaha dalam meningkatkan kesehatan melalui berbagai macam kegiatan Promosi Kesehatan Rumah Sakit.

Terdapat 3 tahap untuk perencanaan terhadap pengembangan Promosi Kesehatan Rumah Sakit (PKRS) dalam Permenkes No. 4 Tahun 2012, yaitu:

1) Menyatukan segala pemahaman dan sikap terhadap mental yang positif dari para direksi, pemilik rumah sakit, dan petugas rumah sakit.

2) Mempersiapkan segala bentuk dan tugas kelembagaan PKRS

3) Mempersiapkan seluruh petugas yang telah memahami semua filosofi, prinsip-prinsip, tujuan dan sarana aksi dari Promosi Kesehatan Rumah Sakit. 


\section{PENUTUP}

Unit PKRS Rumah Sakit Universitas Airlangga telah menjalankan Promosi Kesehatan pada semua bagian, baik di dalam gedung, maupun di luar gedung Rumah Sakit Universitas Airlangga, seperti pada petunjuk teknis promosi kesehatan rumah sakit yang tercantum dalam Permenkes RI Nomor 4 Tahun 2012

Monitoring dan evaluasi bertujuan untuk mengetahui sejauh mana pencapaian kegiatan PKRS berjalan dengan baik, berkesinambungan, dan sesuai dengan standar PKRS. Ada 2 substandar yang harus dilakukan yaitu monitoring dan evaluasi terhadap intervensi promosi kesehatan, yang kedua peninjauan terhadap kebijakan, pedoman/ panduan dan standar operasional prosedur.Kegiatan yang dilakukan mulai dari perencanaan, pelaksanaan serta monitoring dan evaluasi tentang kegiatan promosi kesehatan di rumah sakit dengan sasaran pasien, keluarga pasien, pengunjung dan masyarakat sekitar RS. Kegiatan tersebut berupa edukasi, penyediaan media edukasi, konseling, kerjasama dengan komunitas, juga peningkatan kapasitas SDM RS dengan pelatihan. Namun untuk SDM rumah sakit itu sendiri masih belum dilakukan sepenuhnya, dan hanya edukasi kesehatan saja yang sudah dilakukan.

\section{DAFTAR PUSTAKA}

Anna. F. Machmud, R. Arif, Y. (2018). Analisis Penerapan Upaya Pencapaian Standar Sasaran Keselamatan Pasien Bagi Profesional Pemberi Asuhan Dalam Peningkatan Mutu Pelayanan di Rawat Inap RSUP Dr. M. Djamil Padang Tahun 2017. Jurnal Kesehatan Andalas, Vol 7(4)

Astuti, Syahril A. Painringi, Kadir, R.A. (2018). Pengaruh Elemen People Pada Knowledge Management Terhadap Budaya Keselamatan Pasien di Rsuda.M Parikesit Tenggarong (Influence Element People Of Knowledge Managementto Patient Safety Culture At A.M Parikesit Tenggarong Hospital). JKMM,2(1)

Depkes, Undang-undang Republik Indonesia Nomor 36 Tahun 2009 Tentang Kesehatan, Jakarta: Departemen; 2009 
Firawati. Pabuty. A. Putra, S.A. (2012). Pelaksanaan Program Keselamtan pasien di RSUD Solok. Jurnal Kesehatan Masyarakat. Vol 6(2)

Hendriani,D.A. Hadi,N.E ( 2020). Evaluasi Standar Promosi Kesehatan Rumah Sakit di Rumah Sakit Umum Daerah dr. Soekardjo Kota Tasikmalaya. JUKEMA Vol. 6.(1)

Iskandar,H. Maksum,H. Nafisah.(2014). Faktor Penyebab Penurunan Pelaporan Insiden Keselamatan Pasien Rumah Sakit Factors Influencing Low Hospital Patient Safety Incident Reporting. Jurnal Kedokteran Brawijaya, Vol. 28,(1).

Kemenkes RI. (2011). Permenkes RI No.1691/Menkes/VIII/2011 tentang Keselamatan Pasien Rumah Sakit.

Nurdianna, F. (2017). Pelaksanaan Promosi Kesehatan di Rumah Sakit Universitas Airlangga Surabaya .Jurnal Promkes, Vol 5 (2)

Simamora, R. H., \&Fathi, A. (2019). The Influence Of Training Handover Based SBAR Communication For Improving Patients Safety. Indian journal of public health research \& development, $\operatorname{Vol} 10$ (9)

Sukarip, S. dkk. (2019). Peningkatan Pendidikan Pasien dan Keluarga dengan Penguatan Peran Interpersonal Champion Promosi Kesehatan dengan Pendekatan Teori Peplau. Journal of Hospital Accreditation, Vol.1(1)

Yasmi, Y. Thabrany.H.(2018). Faktor - Faktor Yang Berhubungan Dengan Budaya

Keselamatan Pasien di Rumah Sakit Karya Bhakti Pratiwi Bogor Tahun 2015.Vol 4(2) 
